\title{
MicroRNA-Regulated Ubiquitination and Lipid Metabolism Networks are Associated with Chemotherapy Response in Ovarian Cancer
}

\section{Danai Georgia Topouza}

Department of Biomedical and Molecular Sciences, Queen's University

Jihoon Choi

Department of Biomedical and Molecular Sciences, Queen's University

\section{Sean Nesdoly}

School of Computing, Queen's University

Anastasiya Tarnouskaya

School of Computing, Queen's University

\section{Christopher J.B. Nicol}

Department of Biomedical and Molecular Sciences; Department of Pathology and Molecular Medicine; Cancer Biology and Genetics, Queen's University Cancer Research Institute, Queen's University

Qing Ling Duan ( $\sim$ qingling.duan@queensu.ca)

Department of Biomedical and Molecular Sciences; School of Computing, Queen's University

\section{Research Article}

Keywords: Drug Resistance, Neoplasm, Carcinoma, Ovarian Epithelial, High-Throughput RNA Sequencing, Gene Regulatory Networks, MicroRNAs, Quantitative Trait Loci

Posted Date: August 4th, 2021

DOI: https://doi.org/10.21203/rs.3.rs-452935/v2

License: (a) (1) This work is licensed under a Creative Commons Attribution 4.0 International License. Read Full License 


\section{Abstract}

High-grade serous ovarian cancer (HGSOC) is a highly lethal gynecologic cancer, in part due to resistance to platinum-based chemotherapy reported among $20 \%$ of patients. This study aims to characterize the biological mechanisms underlying chemotherapy resistance, which remain poorly understood.Analysis of mRNA/microRNA sequencing data from HGSOC patients of The Cancer Genome Atlas identified 196 differentially expressed mRNAs enriched for adaptive immunity and translation, and 21 differentially expressed microRNAs associated with angiogenesis. Co-expression network analysis identified two mRNA networks associated with chemotherapy response, which were enriched for ubiquitination and lipid metabolism, as well as three associated microRNA networks enriched for lipoprotein transport and oncogenic pathways. These network modules replicated in two independent ovarian cancer cohorts. Moreover, integrative analyses of the mRNA, microRNA and genomics (i.e. single nucleotide polymorphisms) datasets revealed potential regulation of the mRNA networks by the associated microRNAs and SNPs (i.e. expression quantitative trait loci).Thus, we report novel transcriptional networks and biological pathways associated with resistance to platinum-based chemotherapy among HGSOC patients. These results improve our understanding of the effector networks and regulators of chemotherapy response, which will help to elucidate novel therapeutic targets for ovarian cancer.

\section{Introduction}

High-grade serous ovarian cancer (HGSOC) is a highly lethal gynecologic cancer, in part due to resistance to firstline, platinum-based chemotherapy treatment among $20 \%$ of patients ${ }^{1}$. Chemotherapy resistant patients have a significantly shorter overall survival (OS) than sensitive patients, and many experience tumor recurrence within six months of completing chemotherapy ${ }^{2}$. There is currently no strategy for predicting response to platinum-based chemotherapy, which reflects our limited understanding of the underlying molecular mechanisms of chemoresistance ${ }^{3}$.

The majority of earlier studies reporting gene expression signatures associated with platinum-based chemotherapy resistance in ovarian cancer patients had used univariate analysis methods on transcriptomic data alone $^{4}$. These methods assume that chemotherapy response is driven by a single gene. However, it is well established that chemotherapy response, like other drug response outcomes, is a complex multifactorial trait modulated by multiple genes contributing to common biological pathways ${ }^{5,6}$. To date, few studies have investigated chemotherapy response in ovarian cancer using multivariate methods to identify underlying gene networks or pathways ${ }^{7-11}$. Fewer still incorporated additional types of 'omics data such as microRNA (miRNA) expression and genomics data to study regulation of the gene networks ${ }^{12,13}$. Finally, earlier multivariate transcriptomics studies used RNA microarray data, which do not allow for discovery of novel transcript isoforms $^{14,15}$. In contrast, RNA-sequencing data using next-generation technology include gene transcripts that may have been missed by traditional microarray profiling.

In this study, we apply both univariate and multivariate analysis methods to high-throughput RNA sequencing data from tumors, as well as integrative analysis of germline polymorphisms, in order to identify novel biological pathways and networks associated with chemotherapy response in HGSOC patients. We further determine miRNAs and polymorphisms (i.e. expression quantitative trait loci, eQTLs) correlated with the expression of the associated gene transcripts. These findings are validated using two independent ovarian cancer cohorts and 
improve our understanding of the biological mechanisms underlying resistance to platinum-based chemotherapy in HGSOC patients.

\section{Methods}

\section{Chemotherapy response classification}

Sequencing of mRNA and miRNA was derived from chemotherapy-naïve tumors of 191 and 205 HGSOC patients of TCGA, respectively ${ }^{16}$. Patients who received platinum-based adjuvant chemotherapy were selected and classified for chemotherapy response based on their platinum-free interval. Sensitive patients remained cancerfree for at least 12 months after chemotherapy completion, whereas resistant patients experienced cancer recurrence within 6 months (Table 1; Supplementary Methods). 
Table 1

Characteristics of the HGSOC patient cohorts with mRNA-Seq and miRNA-Seq data from TCGA.

\begin{tabular}{|c|c|c|c|c|c|c|c|c|}
\hline & \multicolumn{4}{|c|}{ mRNA-Seq cohort } & \multicolumn{4}{|c|}{ miRNA-Seq cohort } \\
\hline & Sensitive & Resistant & $\begin{array}{l}P \\
\text { value }\end{array}$ & $\begin{array}{l}\text { All } \\
\text { cases }\end{array}$ & Sensitive & Resistant & $\begin{array}{l}P \\
\text { value }\end{array}$ & $\begin{array}{l}\text { All } \\
\text { cases }\end{array}$ \\
\hline \multicolumn{9}{|l|}{ Age } \\
\hline Mean & 57.15 & 61.98 & $\begin{array}{l}0.0043 \\
a\end{array}$ & 59.22 & 57.76 & 61.52 & $\begin{array}{l}0.018 \\
a\end{array}$ & 59.26 \\
\hline Range & $30-87$ & $38-87$ & & $30-87$ & $30-87$ & $38-87$ & & $30-87$ \\
\hline \multicolumn{9}{|l|}{ Grade } \\
\hline G2 & $\begin{array}{l}18 \\
(15.93 \\
\%)\end{array}$ & $\begin{array}{l}8(10.26 \\
\%)\end{array}$ & $0.27^{b}$ & $\begin{array}{l}26 \\
(13.61 \\
\%)\end{array}$ & $\begin{array}{l}23 \\
(18.70 \\
\%)\end{array}$ & $\begin{array}{l}8(9.76 \\
\%)\end{array}$ & $0.14^{b}$ & $\begin{array}{l}31 \\
(15.12 \\
\%)\end{array}$ \\
\hline $\mathrm{G} 3 / 4$ & $\begin{array}{l}95 \\
(84.07 \\
\%)\end{array}$ & $\begin{array}{l}69 \\
(88.46 \\
\%)\end{array}$ & & $\begin{array}{l}164 \\
(85.86 \\
\%)\end{array}$ & $\begin{array}{l}99 \\
(80.49 \\
\%)\end{array}$ & $\begin{array}{l}73 \\
(89.02 \\
\%)\end{array}$ & & $\begin{array}{l}172 \\
(83.90 \\
\%)\end{array}$ \\
\hline Ungraded & $\begin{array}{l}0(0.00 \\
\%)\end{array}$ & $\begin{array}{l}1(1.28 \\
\%)\end{array}$ & & $\begin{array}{l}1(0.52 \\
\%)\end{array}$ & $\begin{array}{l}1(0.81 \\
\%)\end{array}$ & $\begin{array}{l}1(1.22 \\
\%)\end{array}$ & & $\begin{array}{l}2(0.98 \\
\%)\end{array}$ \\
\hline \multicolumn{9}{|l|}{ Stage } \\
\hline II & $\begin{array}{l}7(6.19 \\
\%)\end{array}$ & $\begin{array}{l}2(2.56 \\
\%)\end{array}$ & $0.48^{b}$ & $\begin{array}{l}9(4.71 \\
\%)\end{array}$ & $\begin{array}{l}8(6.50 \\
\%)\end{array}$ & $\begin{array}{l}2(2.44 \\
\%)\end{array}$ & $0.41^{b}$ & $\begin{array}{l}10 \\
(4.88 \\
\%)\end{array}$ \\
\hline III & $\begin{array}{l}91 \\
(80.53 \\
\%)\end{array}$ & $\begin{array}{l}67(85.9 \\
\%)\end{array}$ & & $\begin{array}{l}158 \\
(82.72 \\
\%)\end{array}$ & $\begin{array}{l}99 \\
(80.49 \\
\%)\end{array}$ & $\begin{array}{l}67 \\
(81.71 \\
\%)\end{array}$ & & $\begin{array}{l}166 \\
(80.98 \\
\%)\end{array}$ \\
\hline IV & $\begin{array}{l}15 \\
(13.27 \\
\%)\end{array}$ & $\begin{array}{l}9(11.54 \\
\%)\end{array}$ & & $\begin{array}{l}24 \\
(12.57 \\
\%)\end{array}$ & $\begin{array}{l}16 \\
(13.01 \\
\%)\end{array}$ & $\begin{array}{l}13 \\
(15.85 \\
\%)\end{array}$ & & $\begin{array}{l}29 \\
(14.15 \\
\%)\end{array}$ \\
\hline \multicolumn{9}{|l|}{$\begin{array}{l}\text { Cytoreductive } \\
\text { surgery outcome }\end{array}$} \\
\hline $\begin{array}{l}\text { Optimal }(\leq \\
10 \mathrm{~mm})\end{array}$ & $\begin{array}{l}73 \\
(64.60 \\
\%)\end{array}$ & $\begin{array}{l}54 \\
(69.23 \\
\%)\end{array}$ & $0.23^{c}$ & $\begin{array}{l}127 \\
(66.49 \\
\%)\end{array}$ & $\begin{array}{l}77 \\
(62.60 \\
\%)\end{array}$ & $\begin{array}{l}56 \\
(68.29 \\
\%)\end{array}$ & $0.21^{c}$ & $\begin{array}{l}133 \\
(64.88 \\
\%)\end{array}$ \\
\hline $\begin{array}{l}\text { Suboptimal (> } \\
\text { 10mm) }\end{array}$ & $\begin{array}{l}26 \\
(23.01 \\
\%)\end{array}$ & $\begin{array}{l}20 \\
(25.64 \\
\%)\end{array}$ & & $\begin{array}{l}46 \\
(24.08 \\
\%)\end{array}$ & $\begin{array}{l}29 \\
(23.58 \\
\%)\end{array}$ & $\begin{array}{l}21 \\
(25.61 \\
\%)\end{array}$ & & $\begin{array}{l}50 \\
(24.39 \\
\%)\end{array}$ \\
\hline Unknown & $\begin{array}{l}14 \\
(12.39 \\
\%)\end{array}$ & $\begin{array}{l}4(5.13 \\
\%)\end{array}$ & & $\begin{array}{l}18 \\
(9.42 \\
\%)\end{array}$ & $\begin{array}{l}17 \\
(13.82 \\
\%)\end{array}$ & $\begin{array}{l}5(6.10 \\
\%)\end{array}$ & & $\begin{array}{l}22 \\
(10.73 \\
\%)\end{array}$ \\
\hline \multicolumn{9}{|l|}{ Overall survival } \\
\hline $\begin{array}{l}\text { Number of } \\
\text { mortality events }\end{array}$ & $\begin{array}{l}48 \\
(42.48 \\
\%)\end{array}$ & $\begin{array}{l}60 \\
(76.92 \\
\%)\end{array}$ & $\begin{array}{l}2.35 \mathrm{E}- \\
06^{\mathrm{c}}\end{array}$ & $\begin{array}{l}108 \\
(56.54 \\
\%)\end{array}$ & $\begin{array}{l}55 \\
(44.72 \\
\%)\end{array}$ & $\begin{array}{l}66 \\
(80.49 \\
\%)\end{array}$ & $\begin{array}{l}0.0002 \\
c\end{array}$ & $\begin{array}{l}121 \\
(59.02 \\
\%)\end{array}$ \\
\hline
\end{tabular}




\begin{tabular}{|c|c|c|c|c|c|c|c|c|}
\hline \multirow[b]{2}{*}{ Median months } & \multicolumn{4}{|c|}{ mRNA-Seq cohort } & \multicolumn{4}{|c|}{ miRNA-Seq cohort } \\
\hline & 52.04 & 28.20 & $\begin{array}{l}6.97 \mathrm{E}- \\
10^{\mathrm{a}}\end{array}$ & 39.87 & 51.91 & 28.20 & $\begin{array}{l}1.13 \mathrm{E}- \\
10^{\mathrm{a}}\end{array}$ & 39.50 \\
\hline $95 \% \mathrm{Cl}$ & $\begin{array}{l}50.07- \\
54.01\end{array}$ & $\begin{array}{l}26.22- \\
30.18\end{array}$ & & $\begin{array}{l}37.90- \\
41.85\end{array}$ & $\begin{array}{l}49.94- \\
53.88\end{array}$ & $\begin{array}{l}26.23- \\
30.18\end{array}$ & & $\begin{array}{l}37.53- \\
41.47\end{array}$ \\
\hline \multicolumn{9}{|c|}{ Adjuvant chemotherapy regimen } \\
\hline $\begin{array}{l}\text { Platinum agent } \\
\text { only }\end{array}$ & $\begin{array}{l}4(3.54 \\
\%)\end{array}$ & $\begin{array}{l}3(3.85 \\
\%)\end{array}$ & $1^{b}$ & $\begin{array}{l}7(3.66 \\
\%)\end{array}$ & $\begin{array}{l}4(3.25 \\
\%)\end{array}$ & $\begin{array}{l}4(4.88 \\
\%)\end{array}$ & $0.71^{b}$ & $\begin{array}{l}8(3.90 \\
\%)\end{array}$ \\
\hline $\begin{array}{l}\text { Platinum/Taxane } \\
\text { combination }\end{array}$ & $\begin{array}{l}109 \\
(96.46 \\
\%)\end{array}$ & $\begin{array}{l}75 \\
(96.15 \\
\%)\end{array}$ & & $\begin{array}{l}184 \\
(96.34 \\
\%)\end{array}$ & $\begin{array}{l}119 \\
(96.75 \\
\%)\end{array}$ & $\begin{array}{l}78 \\
(95.12 \\
\%)\end{array}$ & & $\begin{array}{l}197 \\
(96.10 \\
\%)\end{array}$ \\
\hline \multicolumn{9}{|l|}{$\begin{array}{l}\text { Primary tumor } \\
\text { mRNA subtype }\end{array}$} \\
\hline Differentiated & $\begin{array}{l}37 \\
(32.74 \\
\%)\end{array}$ & $\begin{array}{l}22 \\
(28.21 \\
\%)\end{array}$ & $0.49^{b}$ & $\begin{array}{l}59 \\
(30.89 \\
\%)\end{array}$ & $\begin{array}{l}42 \\
(34.15 \\
\%)\end{array}$ & $\begin{array}{l}24 \\
(29.27 \\
\%)\end{array}$ & $0.68^{c}$ & $\begin{array}{l}66 \\
(32.20 \\
\%)\end{array}$ \\
\hline Immunoreactive & $\begin{array}{l}23 \\
(20.35 \\
\%)\end{array}$ & $\begin{array}{l}10 \\
(12.82 \\
\%)\end{array}$ & & $\begin{array}{l}33 \\
(17.28 \\
\%)\end{array}$ & $\begin{array}{l}24 \\
(19.51 \\
\%)\end{array}$ & $\begin{array}{l}13 \\
(15.85 \\
\%)\end{array}$ & & $\begin{array}{l}37 \\
(18.05 \\
\%)\end{array}$ \\
\hline Mesenchymal & $\begin{array}{l}22 \\
(19.47 \\
\%)\end{array}$ & $\begin{array}{l}18 \\
(23.08 \\
\%)\end{array}$ & & $\begin{array}{l}40 \\
(20.94 \\
\%)\end{array}$ & $\begin{array}{l}24 \\
(19.51 \\
\%)\end{array}$ & $\begin{array}{l}18 \\
(21.95 \\
\%)\end{array}$ & & $\begin{array}{l}42 \\
(20.49 \\
\%)\end{array}$ \\
\hline Proliferative & $\begin{array}{l}30 \\
(26.55 \\
\%)\end{array}$ & $\begin{array}{l}27 \\
(34.62 \\
\%)\end{array}$ & & $\begin{array}{l}57 \\
(29.84 \\
\%)\end{array}$ & $\begin{array}{l}33 \\
(26.83 \\
\%)\end{array}$ & $\begin{array}{l}27 \\
(32.93 \\
\%)\end{array}$ & & $\begin{array}{l}60 \\
(29.27 \\
\%)\end{array}$ \\
\hline $\begin{array}{l}\text { Subtype } \\
\text { unknown }\end{array}$ & $\begin{array}{l}1(0.88 \\
\%)\end{array}$ & $\begin{array}{l}1(1.28 \\
\%)\end{array}$ & & $\begin{array}{l}2(1.05 \\
\%)\end{array}$ & $\begin{array}{l}0(0.00 \\
\%)\end{array}$ & $\begin{array}{l}0(0.00 \\
\%)\end{array}$ & & $\begin{array}{l}0(0.00 \\
\%)\end{array}$ \\
\hline Total patients & 113 & 78 & & 191 & 123 & 82 & & 205 \\
\hline
\end{tabular}

\section{Processing of sequencing data}

Sequencing reads from mRNA were downloaded as FASTQ files (i.e. level 1 data from TCGA), filtered for basequality, aligned, and quantified (detailed in Supplementary Methods). Sequencing of miRNA data were downloaded as quantified expression files (i.e. level 3 data from TCGA). Both mRNA and miRNA datasets underwent outlier detection, normalization, and non-specific filtering, resulting in 49,116 mRNA and 4,479 miRNA transcripts for further analyses.

\section{Differential expression analysis}

Differentially expressed mRNA and miRNA transcripts were detected between sensitive and resistant patients using a negative binomial generalized linear model (GLM) in the DESeq2 R package ${ }^{17}$. This analysis controlled 
for patients' ages at diagnosis, as resistant patients were significantly older (Table 1). The Benjamini-Hochberg method corrected for multiple testing.

\section{Weighted correlation network analysis}

The weighted correlation network analysis (WGCNA) R package ${ }^{18}$ was used to identify modules of co-expressed mRNA and miRNA transcripts using an unsupervised machine learning approach. The first principal component of expression values was calculated for each transcript module, resulting in an eigengene value. Module eigengenes were used to determine association with chemotherapy response using a GLM, adjusted for patients' age as a covariate (Supplementary Methods).

\section{Pathway enrichment analysis}

Pathway enrichment analysis was used to determine over-representation of biological pathways from lists of differentially expressed transcripts (mRNA and miRNAs) and co-expression networks (Supplementary Methods).

\section{eQTL analysis}

Germline single nucleotide polymorphisms (SNPs) from TCGA-HGSOC patients were imputed as described by Choi et al. ${ }^{13}$ before undergoing quality control and linkage disequilibrium-based pruning, retaining 1,722,608 common SNPs for analysis. SNPs were integrated with patient mRNA-seq data $(n=167)$ and miRNA-seq data $(n=$ 178) to identify correlations with transcript expression (eQTLs) using the MatrixEQTL R package ${ }^{19}$ (Supplementary Methods).

\section{mRNA-microRNA integration}

Potential regulation of mRNA networks by miRNAs was tested using data from 165 patients by applying the Spearman correlation of module eigengenes from the mRNA and miRNA co-expression networks. Results were validated using miRNet ${ }^{20}$, a database of experimentally validated mRNA-miRNA interactions, and miRGate ${ }^{21}$, a database of predicted mRNA-miRNA interactions based on ribonucleotide motif matching.

\section{Replication cohort and analysis}

Our results were replicated using two independent ovarian cancer cohorts. First, mRNA results were replicated in the Australian Ovarian Cancer Study cohort (AOCS; GSE9891; $n=285)^{22}$. Next, miRNA results were replicated in the Multicenter Italian Trial in Ovarian cancer cohort (MITO; GSE25204; $n=130)^{23}$. Replication of differentially expressed transcripts used the auto cut-off Kaplan-Meier analysis method from the KM Plotter tool ${ }^{24}$ to test the association of each transcript with progression-free survival (PFS) in the AOCS and MITO cohorts. Validation of transcript networks used the Prognostic Index estimation method from the SurvExpress tool ${ }^{25}$ to test the association of mRNA and miRNA networks with PFS in the above cohorts (Supplementary Methods).

\section{Results}

\section{Differentially expressed mRNAs and miRNAs between sensitive and resistant patients}

Differential expression analysis identified 196 mRNAs associated with chemotherapy response (adjusted $p<0.05$ ) that map to 190 unique genes (Fig. 1A, Supplementary Table S1). Pathway enrichment analysis of these 
associated transcripts indicated enrichment of 41 annotation terms, including B-cell receptor regulation, complement activation, and peptide chain elongation (Supplementary Table S2).

Differential miRNA expression analysis revealed 21 differentially expressed miRNA isoforms (adjusted $p<0.05$ ), which map to 16 unique miRNAs (Fig. 1B, Supplementary Table S3). Pathway enrichment analysis of these miRNA isoforms revealed 16 pathways, such as blood vessel morphogenesis and negative regulation of autophagy (Supplementary Table S2).

\section{mRNA co-expression networks involved in protein ubiquitination and fatty acid metabolism associated with chemotherapy response}

WGCNA of the mRNA transcripts resulted in 58 co-expression modules, of which two were associated with platinum-based chemotherapy (Supplementary Table S4). First, the lavenderblush 3 module is negatively associated with chemotherapy resistance $(p=0.016$, log OR $=-5.40)$. This module contains 39 transcripts, mapping to 31 unique genes (Fig. 2A, Supplementary Table S5). Pathway analysis indicates enrichment of biological pathways related to protein ubiquitination, and the binding motif for the transcription factor GABPalpha (Supplementary Table S2). Second, the darkolivegreen module is significantly upregulated in chemoresistant patients $(p=0.032$, log $O R=13.63)$ and contains 82 transcripts mapping to 80 unique genes (Fig. 2A, Supplementary Table S5). This module is significantly enriched for the protein-containing complex term, as well as for 8 pathways involved in fatty acid metabolism with nominal significance (Supplementary Table S2).

\section{miRNA co-expression networks involved in lipid transport and oncogenic pathways associated with chemotherapy response}

WGCNA analysis of the miRNA dataset constructed 100 co-expression modules (Supplementary Table S6), of which three are associated with chemotherapy response. The ivory $(p=0.0098, \log O R=-5.67)$ and lightcoral $(p=$ 0.042 , log $\mathrm{OR}=-4.36)$ modules are negatively associated with chemotherapy resistance, while the third plum network $(p=0.045, \log O R=4.29)$ is positively associated with chemotherapy resistance. The ivory network consisted of 25 miRNA isoforms mapping to 11 unique miRNAs (Fig. 2B, Supplementary Table S7), which are enriched for 7 pathways and functions, including regulation of lipoprotein transport and cholesterol efflux (Supplementary Table S2). The lightcora/module consists of 17 isoforms of miR-187 and the plum network consists of 17 isoforms of miR-221 and miR-222 (Fig. 2B, Supplementary Table S7). While no pathway annotations were derived for the lighcoral module, the plum module is enriched for 18 pathways and oncogenic functions, such as inhibition of the TRAIL-activated apoptotic pathway and inflammatory cytokine production, and up-regulation of protein kinase B signaling (Supplementary Table S2).

\section{Germline eQTLs may regulate the expression of associated mRNAs, miRNAs, and networks}

Integrative analysis with germline SNP data identified 268 unique cis-eQTLs associated with the expression of significant mRNAs and miRNAs (Supplementary Table S8). A total of 248 SNPs are associated with the expression of 55 significant mRNAs, and 20 SNPs are associated with the expression of 7 significant miRNAs. Of the 268 eQTLs, 118 are novel whereas 126 are previously known, and 24 are not yet recorded in the annotation database. The majority (227) are predicted to alter regulatory motifs, and 67 are associated with 94 human 
phenotypes from published genome-wide association studies. The most common phenotypes are related to triglycerides, high-density lipoprotein (HDL), and low-density lipoprotein (LDL) cholesterol.

\section{Network integration reveals miRNA-mediated regulation of chemotherapy response mechanisms}

Integration of the associated mRNA and miRNA networks determine that the plum miRNA network significantly correlates with the lavenderblush3 mRNA network (Spearman's $\rho=-0.26, p<0.001$ ), and the ivory miRNA network significantly correlates with the darkolivegreen mRNA network (Spearman's $\rho=-0.17, p=0.023$ ). Annotations using miRNet and miRGate determined that 20 of these mRNA-miRNA interactions are experimentally validated, while 15 others are supported by in silico predictions (Table 2, Supplementary Tables S9-S10). Combined with the potential cis-eQTL regulation of mRNAs and miRNAs in these networks, these results reveal an integrative, multiomics view of transcriptional networks associated with chemotherapy response in ovarian cancer (Fig. 3). 


\section{Table 2. Predicted and validated mRNA - miRNA network interactions.}

\begin{tabular}{|c|c|c|c|c|c|c|}
\hline $\begin{array}{l}\text { Integrated } \\
\text { Networks }\end{array}$ & Gene ID & mRNA ID & $\begin{array}{l}\text { miRNA } \\
\text { ID }\end{array}$ & $\begin{array}{l}\text { Spearman's } \\
\rho\end{array}$ & $P$ value & $\begin{array}{l}\text { Interaction } \\
\text { type }\end{array}$ \\
\hline \multirow[t]{15}{*}{$\begin{array}{l}\text { lavenderblush3 } \\
\text { - plum }\end{array}$} & PSIP1 & ENST00000397519 & $\begin{array}{l}\text { hsa- } \\
\text { mir- } \\
222-3 p\end{array}$ & -0.32 & 0.000021 & $\begin{array}{l}\text { Experimental } \\
\text { validation }\end{array}$ \\
\hline & CDC37L1 & ENST00000381854 & $\begin{array}{l}\text { hsa- } \\
\text { mir- } \\
222-3 p\end{array}$ & -0.31 & 0.000042 & $\begin{array}{l}\text { Computational } \\
\text { prediction }\end{array}$ \\
\hline & $C D C 37 L 1$ & ENST00000381854 & $\begin{array}{l}\text { hsa- } \\
\text { mir- } \\
221-3 p\end{array}$ & -0.27 & 0.00034 & $\begin{array}{l}\text { Computational } \\
\text { prediction }\end{array}$ \\
\hline & CDC37L1 & ENST00000381854 & $\begin{array}{l}\text { hsa- } \\
\text { mir- } \\
221-5 p\end{array}$ & -0.27 & 0.00034 & $\begin{array}{l}\text { Computational } \\
\text { prediction }\end{array}$ \\
\hline & $N F I B$ & ENST00000380959 & $\begin{array}{l}\text { hsa- } \\
\text { mir- } \\
221-3 p\end{array}$ & -0.27 & 0.00039 & $\begin{array}{l}\text { Experimental } \\
\text { validation }\end{array}$ \\
\hline & SMU1 & ENST00000397149 & $\begin{array}{l}\text { hsa- } \\
\text { mir- } \\
221-5 p\end{array}$ & -0.26 & 0.00082 & $\begin{array}{l}\text { Experimental } \\
\text { validation }\end{array}$ \\
\hline & $V C P$ & ENST00000358901 & $\begin{array}{l}\text { hsa- } \\
\text { mir- } \\
222-3 p\end{array}$ & -0.25 & 0.00089 & $\begin{array}{l}\text { Experimental } \\
\text { validation }\end{array}$ \\
\hline & CAAP1 & ENST00000333916 & $\begin{array}{l}\text { hsa- } \\
\text { mir- } \\
222-5 p\end{array}$ & -0.22 & 0.0041 & $\begin{array}{l}\text { Computational } \\
\text { prediction }\end{array}$ \\
\hline & CAAP1 & ENST00000333916 & $\begin{array}{l}\text { hsa- } \\
\text { mir- } \\
221-5 p\end{array}$ & -0.21 & 0.0076 & $\begin{array}{l}\text { Computational } \\
\text { prediction }\end{array}$ \\
\hline & TOPORS & ENST00000360538 & $\begin{array}{l}\text { hsa- } \\
\text { mir- } \\
221-3 p\end{array}$ & -0.19 & 0.014 & $\begin{array}{l}\text { Experimental } \\
\text { validation }\end{array}$ \\
\hline & SLC25A51 & ENST00000496760 & $\begin{array}{l}\text { hsa- } \\
\text { mir- } \\
222-3 p\end{array}$ & -0.19 & 0.016 & $\begin{array}{l}\text { Experimental } \\
\text { validation }\end{array}$ \\
\hline & PPAPDC2 & ENST00000381883 & $\begin{array}{l}\text { hsa- } \\
\text { mir- } \\
222-5 p\end{array}$ & -0.18 & 0.021 & $\begin{array}{l}\text { Computational } \\
\text { prediction }\end{array}$ \\
\hline & $V C P$ & ENST00000358901 & $\begin{array}{l}\text { hsa- } \\
\text { mir- } \\
221-3 p\end{array}$ & -0.17 & 0.023 & $\begin{array}{l}\text { Experimental } \\
\text { validation }\end{array}$ \\
\hline & $V C P$ & ENST00000358901 & $\begin{array}{l}\text { hsa- } \\
\text { mir- } \\
221-5 p\end{array}$ & -0.17 & 0.023 & $\begin{array}{l}\text { Experimental } \\
\text { validation }\end{array}$ \\
\hline & $N F X 1$ & ENST00000379540 & hsa- & -0.17 & 0.027 & Computational \\
\hline
\end{tabular}




\begin{tabular}{|c|c|c|c|c|c|c|}
\hline & & & $\begin{array}{l}\text { mir- } \\
221-5 p\end{array}$ & & & prediction \\
\hline & PPAPDC2 & ENST00000381883 & $\begin{array}{l}\text { hsa- } \\
\text { mir- } \\
221-5 p\end{array}$ & -0.17 & 0.03 & $\begin{array}{l}\text { Computational } \\
\text { prediction }\end{array}$ \\
\hline & DNAJA1 & ENST000000330899 & $\begin{array}{l}\text { hsa- } \\
\text { mir- } \\
221-5 p\end{array}$ & -0.16 & 0.035 & $\begin{array}{l}\text { Experimental } \\
\text { validation }\end{array}$ \\
\hline & $A K 3$ & ENST00000381809 & $\begin{array}{l}\text { hsa- } \\
\text { mir- } \\
222-5 p\end{array}$ & -0.16 & 0.037 & $\begin{array}{l}\text { Computational } \\
\text { prediction }\end{array}$ \\
\hline $\begin{array}{l}\text { darkolivegreen } \\
\text { - ivory }\end{array}$ & RPL 18 & ENST00000552347 & $\begin{array}{l}\text { hsa- } \\
\text { mir- } \\
212-3 p\end{array}$ & -0.29 & 0.00017 & $\begin{array}{l}\text { Experimental } \\
\text { Validation }\end{array}$ \\
\hline & MRPL55 & ENST00000411464 & $\begin{array}{l}\text { hsa- } \\
\text { miR- } \\
1306- \\
5 p\end{array}$ & -0.25 & 0.001 & $\begin{array}{l}\text { Computational } \\
\text { prediction }\end{array}$ \\
\hline & FASTK & ENST00000466855 & $\begin{array}{l}\text { hsa- } \\
\text { mir- } \\
140-3 p\end{array}$ & -0.25 & 0.0013 & $\begin{array}{l}\text { Experimental } \\
\text { Validation }\end{array}$ \\
\hline & RPL 18 & ENST00000552347 & $\begin{array}{l}\text { hsa- } \\
\text { mir- } \\
\text { 361-3p }\end{array}$ & -0.24 & 0.0021 & $\begin{array}{l}\text { Experimental } \\
\text { Validation }\end{array}$ \\
\hline & ACBD4 & ENST000000321854 & $\begin{array}{l}\text { hsa- } \\
\text { miR- } \\
128-2- \\
5 p\end{array}$ & -0.22 & 0.0041 & $\begin{array}{l}\text { Computational } \\
\text { prediction }\end{array}$ \\
\hline & $O A Z 1$ & ENST000000581150 & $\begin{array}{l}\text { hsa- } \\
\text { mir- } \\
361-3 p\end{array}$ & -0.22 & 0.0047 & $\begin{array}{l}\text { Experimental } \\
\text { Validation }\end{array}$ \\
\hline & ACBD4 & ENST00000321854 & $\begin{array}{l}\text { hsa- } \\
\text { miR- } \\
128-1- \\
5 p\end{array}$ & -0.21 & 0.0059 & $\begin{array}{l}\text { Computational } \\
\text { prediction }\end{array}$ \\
\hline & $M Y L 12 A$ & ENST00000578611 & $\begin{array}{l}\text { hsa- } \\
\text { mir- } \\
\text { 103a- } \\
3 \mathrm{p}\end{array}$ & -0.17 & 0.023 & $\begin{array}{l}\text { Experimental } \\
\text { Validation }\end{array}$ \\
\hline & MYL12A & ENST000000578611 & $\begin{array}{l}\text { hsa- } \\
\text { mir-107 }\end{array}$ & -0.17 & 0.023 & $\begin{array}{l}\text { Experimental } \\
\text { Validation }\end{array}$ \\
\hline & HTRA2 & ENST00000484352 & $\begin{array}{l}\text { hsa- } \\
\text { mir- } \\
1306- \\
5 p\end{array}$ & -0.17 & 0.029 & $\begin{array}{l}\text { Experimental } \\
\text { Validation }\end{array}$ \\
\hline & ACADVL & ENST000000579425 & $\begin{array}{l}\text { hsa- } \\
\text { mir- } \\
\text { 103a- } \\
3 p\end{array}$ & -0.17 & 0.03 & $\begin{array}{l}\text { Experimental } \\
\text { Validation }\end{array}$ \\
\hline
\end{tabular}




\begin{tabular}{|c|c|c|c|c|c|}
\hline ACADVL & ENST00000579425 & $\begin{array}{l}\text { hsa- } \\
\text { mir-107 }\end{array}$ & -0.17 & 0.03 & $\begin{array}{l}\text { Experimental } \\
\text { Validation }\end{array}$ \\
\hline SOD1 & ENST00000470944 & $\begin{array}{l}\text { hsa- } \\
\text { mir- } \\
140-3 p\end{array}$ & -0.16 & 0.037 & $\begin{array}{l}\text { Experimental } \\
\text { Validation }\end{array}$ \\
\hline RHOT2 & ENST00000569675 & $\begin{array}{l}\text { hsa- } \\
\text { mir- } \\
1306- \\
5 p\end{array}$ & -0.16 & 0.044 & $\begin{array}{l}\text { Experimental } \\
\text { Validation }\end{array}$ \\
\hline TSSK6 & ENST00000360913 & $\begin{array}{l}\text { hsa- } \\
\text { miR- } \\
212-5 p\end{array}$ & -0.15 & 0.048 & $\begin{array}{l}\text { Computational } \\
\text { prediction }\end{array}$ \\
\hline$R C C 1$ & ENST00000373832 & $\begin{array}{l}\text { hsa- } \\
\text { miR- } \\
1306- \\
3 p\end{array}$ & -0.15 & 0.048 & $\begin{array}{l}\text { Computational } \\
\text { prediction }\end{array}$ \\
\hline$R C C 1$ & ENST00000373832 & $\begin{array}{l}\text { hsa- } \\
\text { miR- } \\
1306- \\
5 p\end{array}$ & -0.15 & 0.048 & $\begin{array}{l}\text { Computational } \\
\text { prediction }\end{array}$ \\
\hline
\end{tabular}

\section{Replication of study results in two independent ovarian cancer cohorts}

Replication analysis of the differentially expressed mRNAs used RNA microarray data from the AOCS cohort (Supplementary Table S11). The lavenderblush3 and darkolivegreen mRNA network modules replicated in the AOCS cohort $(p=1.6 e-10, \log H R=-1.27$ and $p=1.3 e-10, \log H R=-1.27$, respectively) (Fig. 4A, B).

Replication of the differentially expressed miRNAs used miRNA-seq data from the BLCA cohort of TCGA (Supplementary Table S12). The ivory and plum miRNA network modules replicated in the MITO cohort ( $p=6.1 \mathrm{e}-$ $4, \log H R=-0.78$ and $p=0.022, \log H R=-0.52$, respectively), while the lightcora/ module reached nominal significance $(p=0.057$, log HR = -0.43) (Fig. 4C-E).

\section{Discussion}

In this study, we analyzed mRNA and miRNA sequencing data from chemotherapy-naïve tumors of HGSOC patients to identify transcripts and networks associated with chemotherapy response. Our findings implicate novel and known biological pathways that replicated in independent cancer cohorts. In addition, we identified potential interactions among miRNAs and mRNAs, as well as eQTLs that potentially regulate the associated transcripts. Thus, our results provide an integrative, multi-omics view of biological networks associated with chemotherapy response.

We identified one mRNA co-expression network (lavenderblush3) significantly upregulated in platinum sensitive patients, which replicated in the AOCS. This module consists of genes involved in ubiquitin-mediated proteolysis in the endoplasmic reticulum (ER). We also detected a significant downregulation of genes responsible for translation initiation in sensitive patients. These findings suggest that the unfolded protein response (UPR), a cellular process responsible for resolving ER stress, may be increasingly activated in sensitive patients compared to resistant cases. The UPR alleviates ER stress through several pathways, including increased ER-associated 
protein degradation (ERAD) to remove misfolded proteins, and inhibition of translation to reduce protein load in the $\mathrm{ER}^{26}$. ER stress promotes cisplatin resistance in OC cell lines ${ }^{27}$ and the upregulation of ERAD genes such as $V C P$ in the lavenderblush 3 module is associated with longer OS and platinum sensitivity in HGSOC cohorts ${ }^{13,28}$. Finally, the lavenderblush3 genes VCP, DNAJA1, and TOPORS are overexpressed in platinum-sensitive HGSOC patients as part of a cell cycle and damage response-associated network ${ }^{12}$.

We identified a second mRNA co-expression network associated with chemotherapy resistance in our HGSOC cohort that replicated in the AOCS. The darkolivegreen module included genes associated with fatty acid metabolism (SREBF1, ACAA1, ACADU), and the protein kinase B oncogene ( $A K T 1)$, which promotes de-novo lipid biosynthesis in cancer ${ }^{29}$. SREBF1 is a key enzyme for cholesterol and fatty acid synthesis, and an essential gene for OC tumor growth ${ }^{30}$. Specifically, SREBF1 is activated by $A K T 1$, promoting fatty acid synthesis ${ }^{31}$, which favors cell proliferation in $\mathrm{OC}^{32}$. Expression of $A C A D V L$, involved in the $\beta$-oxidation of long-chain fatty acids, is linked to $\mathrm{OC}$ metastasis and cell survival ${ }^{33}$. Our findings indicate the upregulation of these lipid metabolism genes among chemotherapy resistant patients. Lipid metabolism dysregulation activates the UPR, which triggers lipid metabolism-based adaptations in the cell through several pathways, including SREBF1 regulation ${ }^{34}$. The interaction of these pathways may present a link between our two gene co-expression modules and warrants further study.

Differential expression analysis identified a downregulation of mRNA transcripts involved in the adaptive immune system, which is associated with chemoresistance. Previous studies reported that a high tumor immune score is a strong predictor of chemosensitivity in $\mathrm{HGSOC}^{35}$. In addition, there are potential links between this immune response activation, UPR and lipid metabolism. ER stress can induce pro-inflammatory cytokine production and UPR activation in tumor cells ${ }^{36}$, which can disrupt dendritic cell function in the OC tumor microenvironment ${ }^{37}$. Moreover, dendritic cell function can also be inhibited by increased lipid uptake in various cancers ${ }^{38}$.

The ivory miRNA co-expression network module, associated with chemotherapy sensitivity in HGSOC and BLCA, is involved in the negative regulation of lipid transport. This enrichment is mainly mediated by miR-128-1 and miR128-2, which play a key role in cholesterol and lipid homeostasis through their suppression of the ABCA1 cholesterol efflux transporter and the low-density lipoprotein receptor (LDLR) ${ }^{39,40}$. MiR-148a is also a regulator of these key genes ${ }^{39}$, which is significantly downregulated in resistant patients. The overexpression of $A B C A 1$ is associated with reduced survival in OC patients ${ }^{41}$, and levels of LDLR are increased in chemoresistant OC cell lines ${ }^{42}$. In addition, overexpression of miR-128 promotes sensitivity to cisplatin in previously resistant OC cells ${ }^{43}$. Our results are consistent with the chemosensitivity-promoting role of miR-128 and its potential activity in cholesterol efflux inhibition alongside miR-148a in this cohort.

The plum miRNA co-expression network consists of miR-221 and miR-222 isoforms, which have been implicated in the development of chemotherapy resistance in OC. Expression of miR-221/miR-222 transcripts is high in cisplatin-resistant $\mathrm{OC}$ cell lines, and their inhibition increases cellular sensitivity ${ }^{44}$. Over-expression of miR-221 and miR-222 promotes proliferation of OC cell lines ${ }^{45,46}$ and reduced disease-free and overall survival ${ }^{45}$. Thus, our findings are consistent with earlier studies showing increased activity of miR-221 and miR-222 in chemoresistant tumors. 
Integrative analysis of mRNA-seq and miRNA-seq datasets identified potential interactions of the associated transcript co-expression modules. The overexpression of miR-221/222 in resistant patients may be inhibiting the chemosensitivity-associated lavenderblush3 mRNA network, revealing a novel potential mechanism of chemotherapy resistance. This finding, combined with the accumulating evidence of miR-221/miR-222 involvement in chemoresistance, may point to a promising avenue for therapeutic intervention. However, overexpression of miR-221/miR-222 promotes UPR-induced apoptosis in hepatocellular carcinoma (HCC) cells ${ }^{47}$. Additionally, ER stress suppresses miR-221/miR-222 in HCC, promoting resistance to apoptosis. The contribution of this mechanism to chemotherapy response in HGSOC is currently unclear and presents an area for future investigation.

We also identified potential regulation of the darkolivegreen mRNA module by the ivory miRNA network, which may inhibit lipid metabolism in chemotherapy sensitive patients. As increased lipid metabolism by cancer cells is a known mechanism of chemoresistance in HGSOC, this miRNA-mediated inhibition may present a novel mechanism of chemotherapy sensitivity.

Finally, cis-eQTL analysis identified known and novel genomic variants correlated with the expression of mRNAs and miRNAs, which are associated with lipid-related phenotypes. High HDL and triglyceride levels have been correlated with increased cancer stage at diagnosis in OC patients ${ }^{48}$. In addition, advanced-stage OC patients with high LDL levels have a shorter PFS than patients with normal levels ${ }^{49}$. Further investigation of these eQTLs is necessary to further elucidate their role in platinum-based chemotherapy resistance and HGSOC prognosis.

\section{Conclusion}

Our study provides novel insight of the underlying mechanisms modulating resistance to platinum-based chemotherapy in HGSOC. Specifically, we conducted whole-transcriptome analysis of mRNA-seq and miRNA-seq data to generate novel mechanistic hypotheses using both univariate and network methods. Moreover, we integrated this data with miRNA-seq and genome-wide SNPs to determine potential regulation of the associated transcripts and networks. Our findings implicate novel and known signaling pathways and networks associated with chemotherapy response in HGSOC as well as regulators, which could become novel drug targets. Further studies are needed to validate these findings in other cancers.

\section{Abbreviations}

AOCS: Australian Ovarian Cancer Study

eQTL: Expression Quantitative Trait Locus

HGSOC: High-Grade Serous Ovarian Cancer

MITO: Multicenter Italian Trial in Ovarian cancer

OC: Ovarian Cancer

OS: Overall Survival

PFS: Progression-Free Survival

Page $13 / 23$ 
TCGA: The Cancer Genome Atlas

WGCNA: Weighted Correlation Network Analysis

\section{Declarations}

\section{Acknowledgements}

Computations in this manuscript were performed on resources and with support provided by the Centre for Advanced Computing (CAC) at Queen's University in Kingston, Ontario. The CAC is funded by the Canada Foundation for Innovation, the Government of Ontario, and Queen's University.

\section{Author contributions}

D.G.T.: Investigation, Formal analysis, Software, Visualization, Validation, Data curation, Writing - original draft, Writing - review \& editing. J.C.: Formal analysis, Software, Data curation, Writing - review \& editing. S.N.: Software, Data curation. A.T.: Data curation. C.J.B.N.: Writing - review \& editing. Q.L.D.: Conceptualization, Supervision, Methodology, Resources, Funding acquisition, Writing - review \& editing.

\section{Ethics approval}

Written informed consent was obtained from all subjects of the Cancer Genome Atlas (TCGA) research project ${ }^{16}$. Data access and research methods were carried out in accordance with relevant guidelines and regulations set by the National Cancer Institute ( $\mathrm{NCl}$ ) and the National Human Genome Research Institute (NHGRI), in compliance with the HIPAA Privacy Rule, and all protocols were approved by the Human Research Ethics Boards at Queen's University.The terms of data access are outlined in the Data Use Certification Agreement: https://dbgap.ncbi.nlm.nih.gov/aa/wga.cgi?view_pdf\&wlid=10654\&tlsid=274. Details of the human subject protection and data access policies implemented by TCGA are as described:https://www.cancer.gov/aboutnci/organization/ccg/research/structural-genomics/tcga/history/policies/tcga-human-subjects-data-policies.pdf.

\section{Consent for publication}

All authors have approved the submission of this manuscript. The results have not been previously published and are not being considered for publication in another journal. An earlier version of this manuscript has been posted onthe bioRxiv non-commercial preprint repository (DOI: https://doi.org/10.1101/2020.09.09.289868) ${ }^{50}$.

\section{Data availability}

Transcriptomics, genomics, and clinical data from the TCGA cohortsupporting the conclusions of this article are available in the Genomic Data Commons (GDC) Data Portal at https://portal.gdc.cancer.gov/, project ID TCGA-OV. Clinical and gene expression data of the AOCS cohort supporting the conclusions of this article are available in the Gene Expression Omnibus (GEO) database at https://www.ncbi.nlm.nih.gov/geo/, reference number GSE9899. Clinical and miRNA expression data of the MITO cohort supporting the conclusions of this article are available in the GEO database at https://www.ncbi.nlm.nih.gov/geo/, reference number GSE25204.

\section{Competing Interests}

The authors declare that they have no competing interests. 


\section{Funding}

D.G.T. is funded by Queen's University and internal awards in the Department of Biomedical and Molecular Sciences. Q.L.D. receives funding from the Canadian Institutes of Health Research and Queen's University National Scholar Award. The funders did not play any role in the study design, data collection, data analysis, data interpretation, writing of the manuscript or decision to publish results.

\section{References}

1 Dion, L. et al. The Landscape and Therapeutic Implications of Molecular Profiles in Epithelial Ovarian Cancer. J Clin Med9, doi:10.3390/jcm9072239 (2020).

2 Davis, A., Tinker, A. V. \& Friedlander, M. "Platinum resistant" ovarian cancer: what is it, who to treat and how to measure benefit? Gynecol Onco/133, 624-631, doi:10.1016/j.ygyno.2014.02.038 (2014).

3 Freimund, A. E., Beach, J. A., Christie, E. L. \& Bowtell, D. D. L. Mechanisms of Drug Resistance in High-Grade Serous Ovarian Cancer. Hematol Oncol Clin North Am32, 983-996, doi:10.1016/j.hoc.2018.07.007 (2018).

4 Lloyd, K. L., Cree, I. A. \& Savage, R. S. Prediction of resistance to chemotherapy in ovarian cancer: a systematic review. BMC Cancer15, 117, doi:10.1186/s12885-015-1101-8 (2015).

5 Kalow, W. Pharmacogenetics and pharmacogenomics: origin, status, and the hope for personalized medicine. Pharmacogenomics J6, 162-165, doi:10.1038/sj.tpj.6500361 (2006).

6 Binju, M. et al. Mechanisms underlying acquired platinum resistance in high grade serous ovarian cancer - a mini review. Biochim Biophys Acta Gen Subj1863, 371-378, doi:10.1016/j.bbagen.2018.11.005 (2019).

7 Spentzos, D. et al. Unique gene expression profile based on pathologic response in epithelial ovarian cancer. $J$ Clin Oncol23, 7911-7918, doi:10.1200/JC0.2005.02.9363 (2005).

8 Bernardini, M. et al. High-resolution mapping of genomic imbalance and identification of gene expression profiles associated with differential chemotherapy response in serous epithelial ovarian cancer. Neoplasia7, 603613, doi:10.1593/neo.04760 (2005).

9 Chen, Y., Bi, F., An, Y. \& Yang, Q. Coexpression network analysis identified Kruppel-like factor 6 (KLF6) association with chemosensitivity in ovarian cancer. J Cell Biochem, doi:10.1002/jcb.27567 (2018).

10 Zhang, L., Zhang, X., Fan, S. \& Zhang, Z. Identification of modules and hub genes associated with platinumbased chemotherapy resistance and treatment response in ovarian cancer by weighted gene co-expression network analysis. Medicine (Baltimore)98, e17803, doi:10.1097/MD.0000000000017803 (2019).

11 Bagnoli, M. et al. Development and validation of a microRNA-based signature (MiROvaR) to predict early relapse or progression of epithelial ovarian cancer: a cohort study. Lancet Onco/17, 1137-1146, doi:10.1016/S1470-2045(16)30108-5 (2016).

12 Benvenuto, G. et al. Expression profiles of PRKG1, SDF2L1 and PPP1R12A are predictive and prognostic factors for therapy response and survival in high-grade serous ovarian cancer. Int J Cancer147, 565-574, 
doi:10.1002/ijc.32935 (2020).

13 Choi, J. et al. Gene networks and expression quantitative trait loci associated with adjuvant chemotherapy response in high-grade serous ovarian cancer. BMC Cancer20, 413, doi:10.1186/s12885-020-06922-1 (2020).

14 Zhang, W. et al. Comparison of RNA-seq and microarray-based models for clinical endpoint prediction. Genome Bio/16, 133, doi:10.1186/s13059-015-0694-1 (2015).

15 Hafner, M. et al. Barcoded cDNA library preparation for small RNA profiling by next-generation sequencing. Methods58, 164-170, doi:10.1016/j.ymeth.2012.07.030 (2012).

16 Cancer Genome Atlas Research, N. Integrated genomic analyses of ovarian carcinoma. Nature474, 609-615, doi:10.1038/nature10166 (2011).

17 Love, M. I., Huber, W. \& Anders, S. Moderated estimation of fold change and dispersion for RNA-seq data with DESeq2. Genome Bio/15, 550, doi:10.1186/s13059-014-0550-8 (2014).

18 Langfelder, P. \& Horvath, S. WGCNA: an R package for weighted correlation network analysis. BMC Bioinformatics9, 559, doi:10.1186/1471-2105-9-559 (2008).

19 Shabalin, A. A. Matrix eQTL: ultra fast eQTL analysis via large matrix operations. Bioinformatics28, 1353-1358, doi:10.1093/bioinformatics/bts163 (2012).

20 Chang, L., Zhou, G., Soufan, O. \& Xia, J. miRNet 2.0: network-based visual analytics for miRNA functional analysis and systems biology. Nucleic Acids Res48, W244-W251, doi:10.1093/nar/gkaa467 (2020).

21 Andres-Leon, E., Gomez-Lopez, G. \& Pisano, D. G. Prediction of miRNA-mRNA Interactions Using miRGate. Methods Mol Bio/1580, 225-237, doi:10.1007/978-1-4939-6866-4_15 (2017).

22 Tothill, R. W. et al. Novel molecular subtypes of serous and endometrioid ovarian cancer linked to clinical outcome. Clin Cancer Res14, 5198-5208, doi:10.1158/1078-0432.CCR-08-0196 (2008).

23 Bagnoli, M. et al. Identification of a chrXq27.3 microRNA cluster associated with early relapse in advanced stage ovarian cancer patients. Oncotarget2, 1265-1278, doi:10.18632/oncotarget.401 (2011).

24 Gyorffy, B., Lanczky, A. \& Szallasi, Z. Implementing an online tool for genome-wide validation of survivalassociated biomarkers in ovarian-cancer using microarray data from 1287 patients. Endocr Relat Cancer19, 197208, doi:10.1530/ERC-11-0329 (2012).

25 Aguirre-Gamboa, R. et al. SurvExpress: an online biomarker validation tool and database for cancer gene expression data using survival analysis. PLoS One8, e74250, doi:10.1371/journal.pone.0074250 (2013).

26 Kim, H., Bhattacharya, A. \& Qi, L. Endoplasmic reticulum quality control in cancer: Friend or foe. Semin Cancer Bio/33, 25-33, doi:10.1016/j.semcancer.2015.02.003 (2015).

27 Tian, J., Liu, R. \& Qu, Q. Role of endoplasmic reticulum stress on cisplatin resistance in ovarian carcinoma. Oncol Lett13, 1437-1443, doi:10.3892/ol.2017.5580 (2017). 
28 Bastola, P., Neums, L., Schoenen, F. J. \& Chien, J. VCP inhibitors induce endoplasmic reticulum stress, cause cell cycle arrest, trigger caspase-mediated cell death and synergistically kill ovarian cancer cells in combination with Salubrinal. Mol Onco/10, 1559-1574, doi:10.1016/j.molonc.2016.09.005 (2016).

29 Koundouros, N. \& Poulogiannis, G. Reprogramming of fatty acid metabolism in cancer. Br J Cancer122, 4-22, doi:10.1038/s41416-019-0650-z (2020).

$30 \mathrm{Nie}$ L. Y. et al. Sterol regulatory element-binding protein 1 is required for ovarian tumor growth. Oncol Rep30, 1346-1354, doi:10.3892/or.2013.2575 (2013).

31 Porstmann, T. et al. PKB/Akt induces transcription of enzymes involved in cholesterol and fatty acid biosynthesis via activation of SREBP. Oncogene24, 6465-6481, doi:10.1038/sj.onc.1208802 (2005).

32 Wang, H. Q. et al. Positive feedback regulation between AKT activation and fatty acid synthase expression in ovarian carcinoma cells. Oncogene24, 3574-3582, doi:10.1038/sj.onc.1208463 (2005).

33 Wheeler, L. J. et al. Multi-Omic Approaches Identify Metabolic and Autophagy Regulators Important in Ovarian Cancer Dissemination. iScience19, 474-491, doi:10.1016/j.isci.2019.07.049 (2019).

34 Pinto, B. A. S., Franca, L. M., Laurindo, F. R. M. \& Paes, A. M. A. Unfolded Protein Response: Cause or Consequence of Lipid and Lipoprotein Metabolism Disturbances? Adv Exp Med Bio/1127, 67-82, doi:10.1007/9783-030-11488-6_5 (2019).

35 Hao, D. et al. Immunogenomic Analyses of Advanced Serous Ovarian Cancer Reveal Immune Score is a Strong Prognostic Factor and an Indicator of Chemosensitivity. Clin Cancer Res24, 3560-3571, doi:10.1158/10780432.CCR-17-3862 (2018).

36 Mahadevan, N. R. et al. Transmission of endoplasmic reticulum stress and pro-inflammation from tumor cells to myeloid cells. Proc Natl Acad Sci U S A108, 6561-6566, doi:10.1073/pnas.1008942108 (2011).

37 Cubillos-Ruiz, J. R. et al. ER Stress Sensor XBP1 Controls Anti-tumor Immunity by Disrupting Dendritic Cell Homeostasis. Cel/161, 1527-1538, doi:10.1016/j.cell.2015.05.025 (2015).

38 Herber, D. L. et al. Lipid accumulation and dendritic cell dysfunction in cancer. Nat Med16, 880-886, doi:10.1038/nm.2172 (2010).

39 Wagschal, A. et al. Genome-wide identification of microRNAs regulating cholesterol and triglyceride homeostasis. Nat Med21, 1290-1297, doi:10.1038/nm.3980 (2015).

40 Adlakha, Y. K. et al. Pro-apoptotic miRNA-128-2 modulates ABCA1, ABCG1 and RXRalpha expression and cholesterol homeostasis. Cell Death Dis4, e780, doi:10.1038/cddis.2013.301 (2013).

41 Hedditch, E. L. et al. ABCA transporter gene expression and poor outcome in epithelial ovarian cancer. $J$ Natl Cancer Inst106, doi:10.1093/jnci/dju149 (2014).

42 Zheng, L., Li, L., Lu, Y., Jiang, F. \& Yang, X. A. SREBP2 contributes to cisplatin resistance in ovarian cancer cells. Exp Biol Med (Maywood)243, 655-662, doi:10.1177/1535370218760283 (2018). 
43 Li, B., Chen, H., Wu, N., Zhang, W. J. \& Shang, L. X. Deregulation of miR-128 in ovarian cancer promotes cisplatin resistance. Int J Gynecol Cancer24, 1381-1388, doi:10.1097/IGC.0000000000000252 (2014).

44 Amini-Farsani, Z., Sangtarash, M. H., Shamsara, M. \& Teimori, H. MiR-221/222 promote chemoresistance to cisplatin in ovarian cancer cells by targeting PTEN/PI3K/AKT signaling pathway. Cytotechnology70, 203-213, doi:10.1007/s10616-017-0134-z (2018).

$45 \mathrm{Li}, \mathrm{J}$. et al. Overexpression of miRNA-221 promotes cell proliferation by targeting the apoptotic protease activating factor-1 and indicates a poor prognosis in ovarian cancer. Int J Oncol, doi:10.3892/ijo.2017.3898 (2017).

46 Sun, C. et al. miR-222 is upregulated in epithelial ovarian cancer and promotes cell proliferation by downregulating P27(kip1.). Oncol Lett6, 507-512, doi:10.3892/ol.2013.1393 (2013).

47 Dai, R. et al. miR-221/222 suppression protects against endoplasmic reticulum stress-induced apoptosis via p27(Kip1)- and MEK/ERK-mediated cell cycle regulation. Biol Chem391, 791-801, doi:10.1515/BC.2010.072 (2010).

48 Zhang, Y. et al. Association of serum lipids and severity of epithelial ovarian cancer: an observational cohort study of 349 Chinese patients. J Biomed Res32, 336-342, doi:10.7555/JBR.32.20170096 (2018).

49 Li, A. J., Elmore, R. G., Chen, I. Y. \& Karlan, B. Y. Serum low-density lipoprotein levels correlate with survival in advanced stage epithelial ovarian cancers. Gynecol Onco/116, 78-81, doi:10.1016/j.ygyno.2009.09.027 (2010).

50 Topouza, D. G. et al. Novel regulatory and transcriptional networks associated with resistance to platinumbased chemotherapy in ovarian cancer. bioRxiv, doi:https://doi.org/10.1101/2020.09.09.289868 (2021).

\section{Figures}



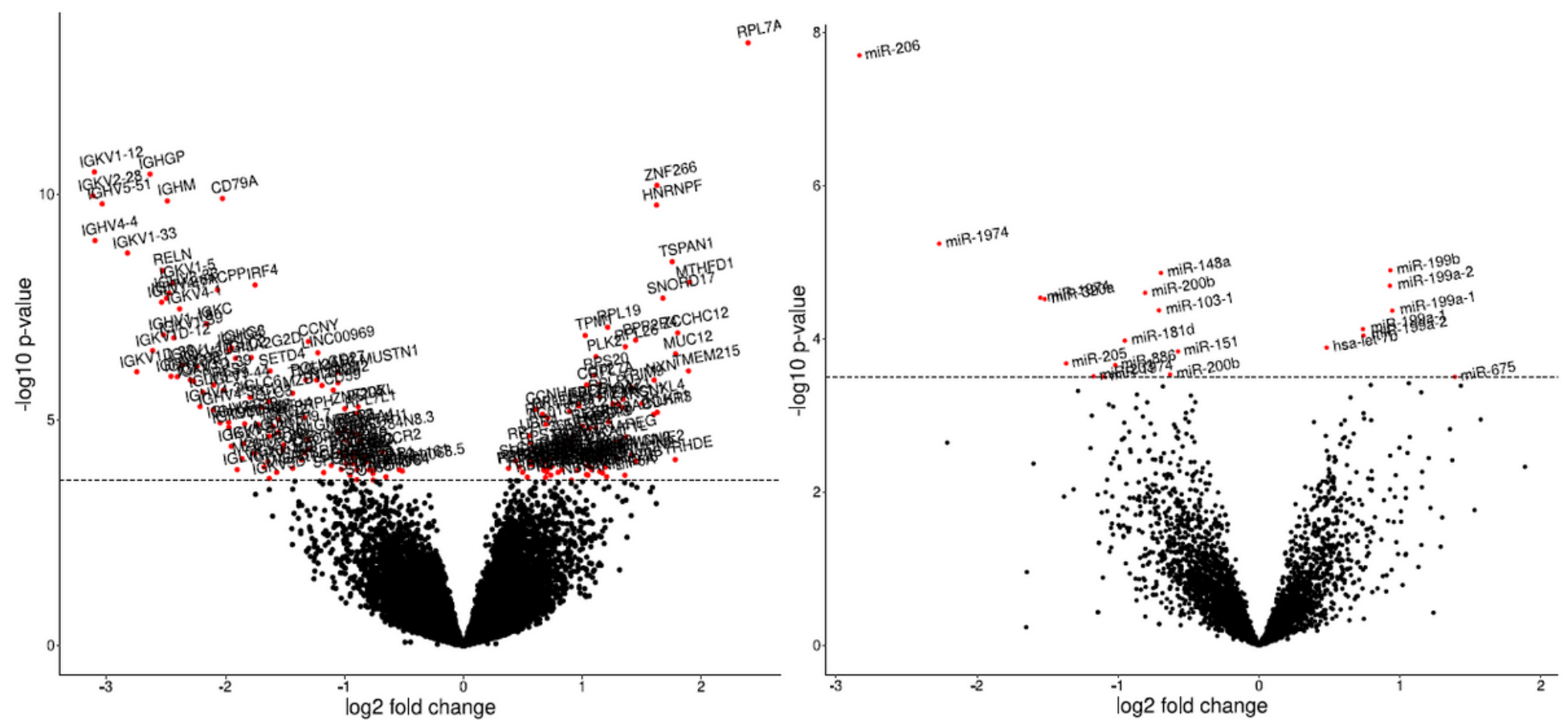

Figure 1

Differential expression analysis of mRNA and miRNA transcripts. (A) Significant differentially expressed mRNA transcripts $(n=196)$ are shown in red. The Benjamini-Hochberg adjusted significance threshold is indicated by the dashed line. Transcripts with a positive fold change are upregulated in resistant patients, whereas transcripts with a negative fold change are downregulated in resistant patients. (B) Significant differentially expressed miRNA isoforms $(n=21)$ are shown in red. The Benjamini-Hochberg adjusted significance threshold is indicated by the dashed line. Transcripts with a positive fold change are upregulated in resistant patients, whereas transcripts with a negative fold change are downregulated in resistant patients. 
(A)

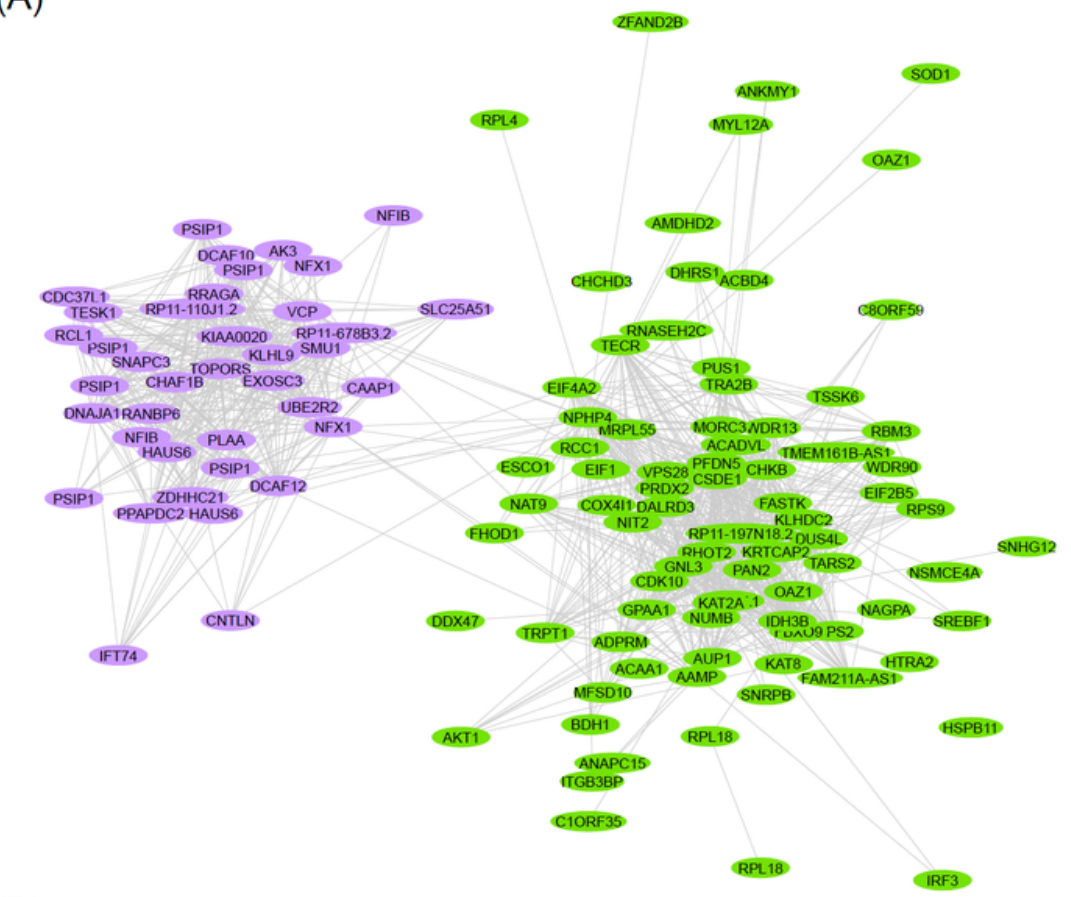

(B)

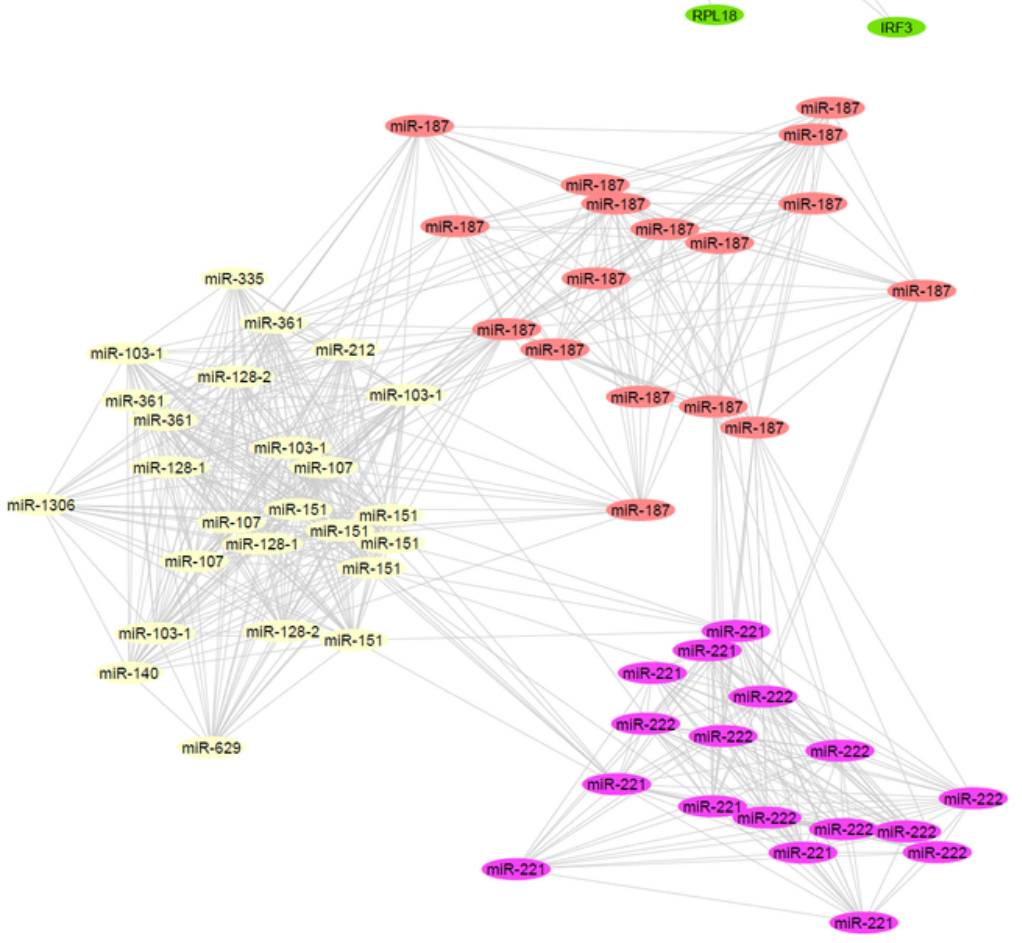

\section{Figure 2}

Weighted correlation network analysis of mRNA and miRNA transcripts. (A) The mRNA modules lavenderblush3 and darkolivegreen are visualized in their respective colors. Each node represents a transcript, and each edge represents a connection or co-expression. The distance between nodes is the connection weight, where more similar transcripts are plotted closer. (B) The miRNA modules lightcoral, plum, and ivory are visualized in their respective colors. Each node represents one miRNA isoform, and each edge represents a connection or coexpression. The distance between nodes is the connection weight, where more similarly expressed transcripts are plotted closer. 


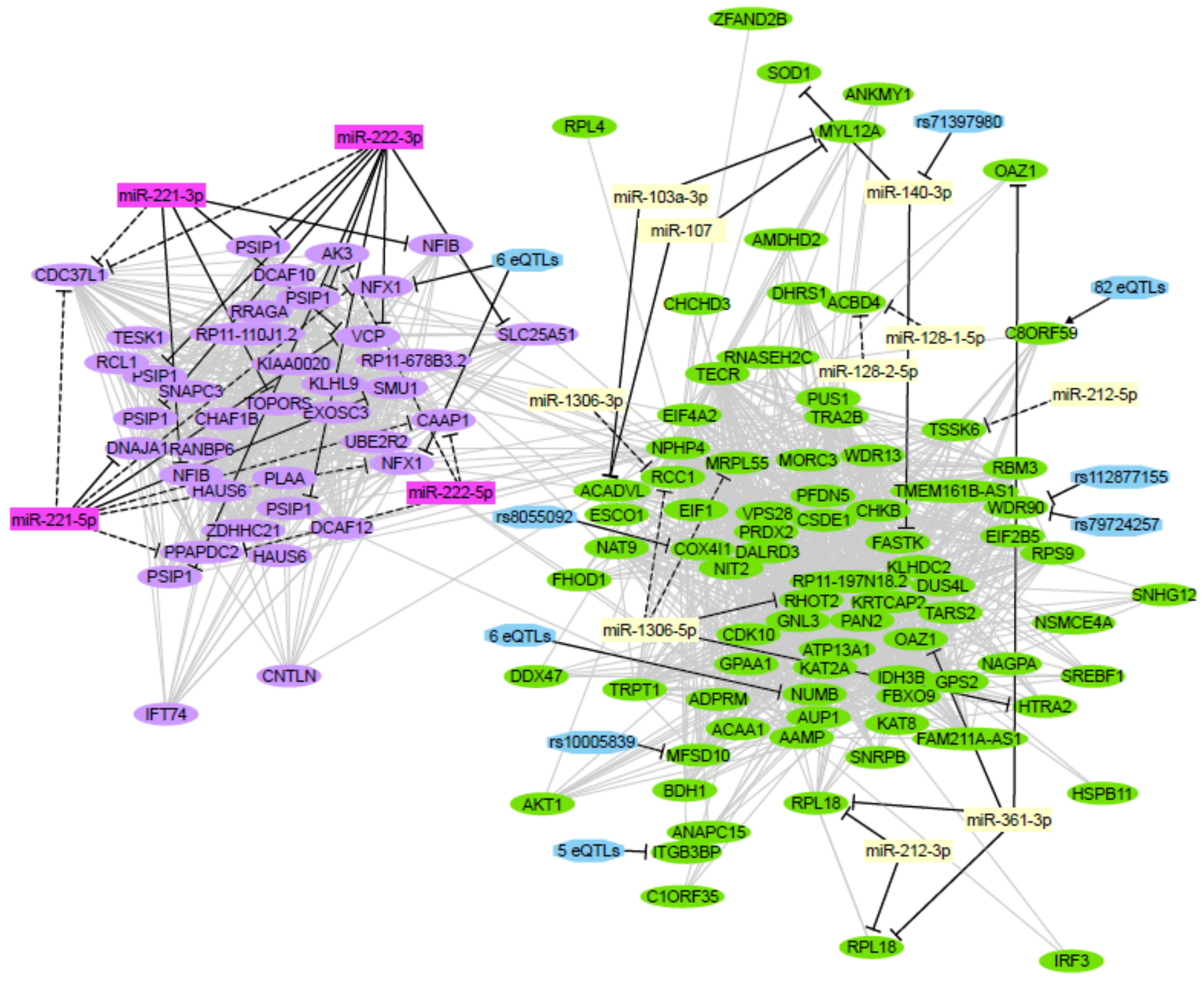

Figure 3

Integration of significant networks. The mRNA transcripts (oval nodes) from the lavenderblush3 and darkolivegreen modules are arranged based on co-expression similarity (grey edges). Regulatory interactions (black edges) indicate inhibition (bar-headed arrow) or activation (arrow). The colors of miRNA nodes indicate their membership in the plum and ivory co-expression networks. Four miRNA isoforms (rectangular nodes) were validated (solid edges) or predicted (dashed edges) to regulate the expression of genes in the lavenderblush3 network module. In addition, 6eQTLs (hexagonal nodes) may regulate the expression of the NFX1 gene. Genesin the darkolivegreen module have 10 validated or predicted regulatory miRNAs and 97 regulatory eQTLs. Finally, the ivory miRNA miR-140 may be regulated by the miR-QTL rs71397980. eQTL, expression quantitative trait loci; miRQTL, microRNA expression quantitative trait loci. 
(A)

lavenderblush3 Prognostic Index Strata - High Risk - Low Risk

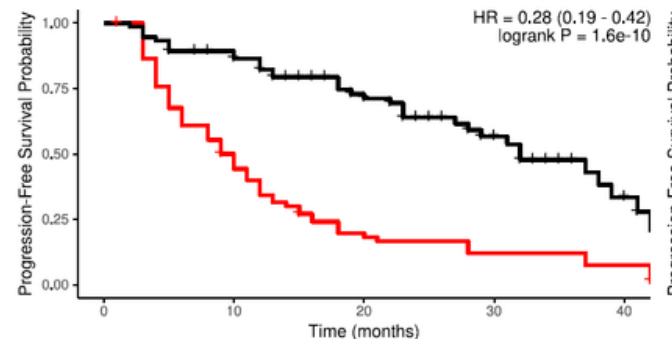

Number at risk

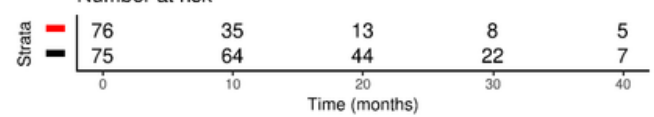

(C)

ivory Prognostic Index
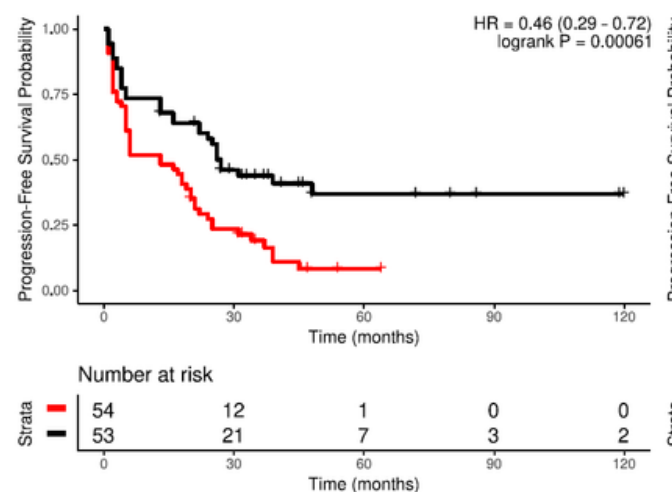

(E)

lightcoral Prognostic Index

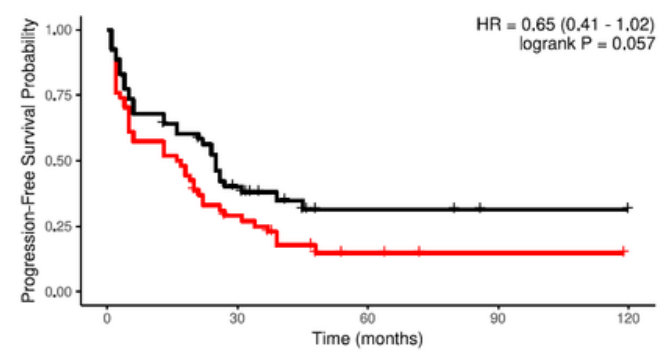

Number at risk

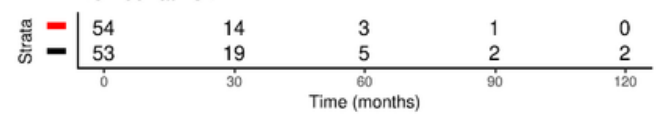

(B)

darkolivegreen Prognostic Index

Strata - High Risk — Low Risk

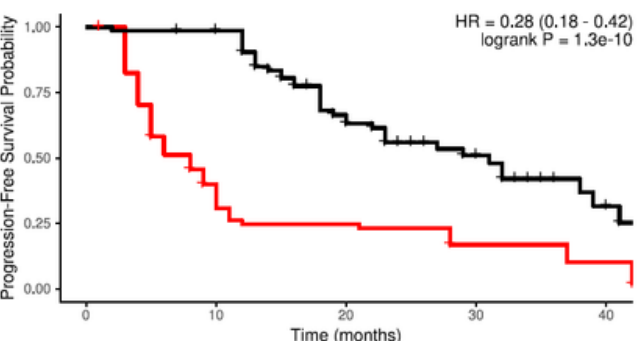

Number at risk
(D)

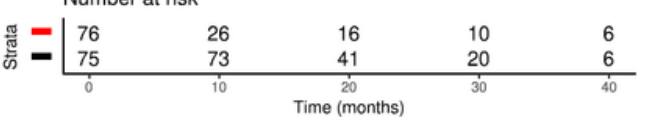

D) plum Prognostic Index

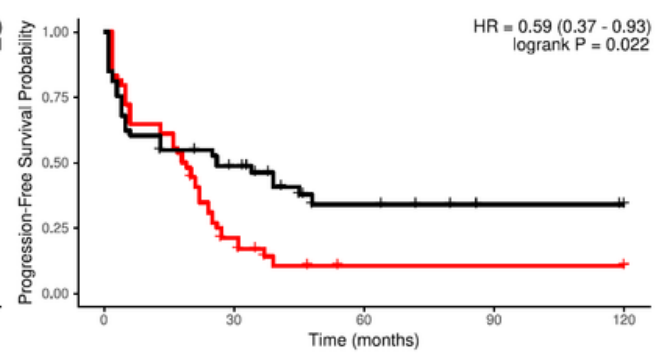

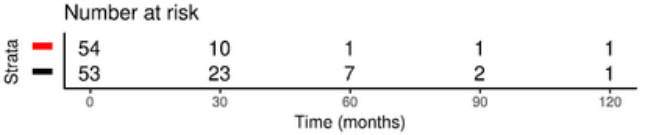

Time (months)

$$
\text { (1) }
$$

\section{Figure 4}

Replication analysis of significanttranscript co-expression networks. (A-B) Kaplan-Meier analysis of patient PFS association with the prognostic index of mRNA networks lavenderblush3 (A) and darkolivegreen (B) in the AOCS cohort. (C-E) Kaplan-Meier analysis of patient PFS association with the prognostic index of miRNA networks ivory (C), plum (D), and lightcoral (E) in the MITO cohort. PFS, progression-free survival; AOCS, Australian Ovarian Cancer Study; MITO, Multicenter Italian Trial in Ovarian cancer.

\section{Supplementary Files}


This is a list of supplementary files associated with this preprint. Click to download.

- Supplementarylnformation.xlsx

- SupplementaryMethods.pdf 